medical services. We believe it is only right that the patient's GP should have access to this information. I would remind you of the criticisms contained within the report of the Inquiry into the care and treatment of Christopher Clunis of the repeated failures of different agencies to pass on information concerning Mr Clunis's incidents of violence. The recent guidance on the new arrangements for the removal of violent patients from GP lists specifically notes that the new powers are not for use in the case of psychiatric patients.

We appreciate the concerns of your members that the process of registering patients and allowing for appeals will cut into time for patient care. However, we believe that where the Care Programme Approach is being implemented, the introduction of registers will not create unmanageable amounts of extra bureaucracy.

\section{Update following the meeting of the Executive and Finance Committee, 4 June 1994}

I should like to report to Members and Fellows of the College the recent developments relating to the introduction of the Supervision Register.

This matters was raised again at the meeting of the College's Executive and Finance Committee on 4 June, at which the Secretary of State for Health's response to my letter of 27 April 1994 was received.

Following my correspondence with the Secretary of State for Health, I have now had an invitation from Dr Rachel Jenkins, Senior Principal Medical Officer at the Department of Health, to meet to discuss the matter. We have agreed
Finally, you draw attention to the recommendations of the report of the Inquiry into the care and treatment of Christopher Clunis, in particular, those proposals for establishing special supervision groups, with new funding. We find this surprising, given the objections you have outlined against supervision registers. The idea of a new national register would raise very considerable anxieties over civil liberties, and offer a far greater risk to the therapeutic relationship than local registers.

We are anxious that psychiatrists work to make supervision registers a successful method of prioritising patients who are at special risk so that their needs are met and they receive the most appropriate care and treatment.

I hope this is helpful.

VIRGINIA BOTTOMLEY

that the College will collaborate with the Department of Health in developing guidelines concerning the implementation of the Register.

I should like to assure Members and Fellows that in view of the level of concern regarding the proposals, the College will in due course be issuing advice to the membership of the College, although it is not clear at this stage whether this will be produced in conjunction with the Department of Health.

I should be interested to hear from any Members or Fellows who can report instances where a Supervision Register is being implemented successfully.

Dr F. CaldicotT, President, Royal College of Psychiatrists 